\title{
Clinical Case of Mastocytosis
}

\section{Makhmudov.F.R ${ }^{1}$, Obeidat M.A ${ }^{2}$ Mizher S.A. $^{3}$}

Azerbaijan Medical University, Department of Dermatovenereology, Azerbaijan.

*Corresponding Author: Makhmudov.F.R., Azerbaijan Medical University, Department of Dermatovenereology, Azerbaijan.

\section{Abstract}

Mastocytosis is a group of diseases caused by tissue infiltration and characterized by the release of biological active substances from mast cells during degranulation. The article presents data on the etiology, pathogenesis, clinical picture, clinical forms, diagnosis and differential diagnosis of mastocytosis, as well as its own clinical observations. The presented clinical case contains the features of a rare clinical form of mastocytosis - telangiectasia macularis eruptive prestans, which is often overlooked by clinicians, as a result of which the patient is not treated promptly. The presented clinical case reflects the relevance of the problem in medical practice. Timely diagnosis of the disease improves the prognosis of the disease.

Keywords: mastocytosis, telangiectasiamacularis eruptive prestans (TMEP).

The disease was first described by E. Nettleship and W. Tay in 1869 under the name "chronic urticaria", which left postpigmentation in the form of brown spots. A. Sangster in 1878 proposed a name for such skin manifestations as "urticariapigmentosa". However, the nature of these lesions was established by P. Unna in 1887 as a result of histological studies. The term "mastocytosis" was introduced by R. Degos in 1953 $[2,3]$.

Mastocytosis is a rare disease. Among skin diseases, for every 1000 patients, there is $0.2-1$ cases of mastocytosis, that is, $2-3$ patients per 10,000 [6]. Mastocytosis has no gender preference, and it occurs in all races[2]. In Europe, approximately 100,000 patients are registered, in the world - 1 million.

With regard to the etiology of mastocytosis, there is no single point of view, most authors suggest that the disease is a pathology of the reticulohistiocytic system. The presence of family cases, including in identical twins, indicates the possible role of genetic factors. It is not excluded autosomal dominant inheritance with variable penetrance, as well as autosomal recessive inheritance. Family cases are quite rare.

In the pathogenesis of mastocytosis, the main role belongs to histamine, heparin, neutral protease and acidic hydrolases $[3,5]$. The release of histamine, heparin, proteases and hydrolases occurs as a result of mast cell degranulation, when the granules from the center move to the periphery and then enter the extracellular space. Mastocyte degranulation occurs when mast cells are exposed to immune and non-immune activators. The mechanism of action of immune activators is associated with the presence of glycoprotein receptors in mast cells, which are sensitive to class E immunoglobulins. In their turn, non-immune activators are represented by drugs, physical factors, bacterial toxins, etc. [1].

Mastocytoma, nodular mastocytosis and urticariapigmentosa develops in $55 \%$ of cases in the first two years of life [7]. For children, as a rule, pathology is limited to skin lesions and is rarely combined with systemic organ damage.

For adults, predominantly systemic mastocytosis occurs, in which in almost half of the patients the skin is not involved in the process. According to the International Classification of Diseases of the 10th revision (mastocytosis, code Q82.2) it is divided into 2 groups: cutaneous and systemic mastocytosis. Urticariapigmentosa,, nodular mastocytosis, diffuse mastocytosis, mastocytoma, telangiectasia macularis eruptiva perstans belong to cutaneous mastocytosis. Systemic mastocytosis includes aggressive systemic 
mastocytosis, mast cell leukemia , mast cell sarcoma, extra cutaneous mastocytoma [2.5].

In $85 \%$ of cases, the skin is affected. Cutaneous mastocytosis can be localized (solitary mastocytoma), generalized, which manifests itself as multiple spots, papules and nodes, as well as telangiectasia macularis eruptiva perstans orerythrodermic (diffuse) mastocytosis $[3,5]$.

The most common is macular mastocytosisurticaria pigmentosa. Occurs more often in children. Generalized skin lesions are found only in $1 \%$ of cases. The disease usually develops in the first 2 years of a child's life and ends with a spontaneous recovery in the puberty [7]. At the onset of the disease, itchy pinkred spots appear, which are subsequently transformed into blisters. Regression of the wheals leads to the formation of brownmaculas, on the background of which papular elements further appear. In adults, the skin process begins immediately with the appearance of maculopapular elements. The maculas have rounded outlines with clear borders, up to $0.5 \mathrm{~cm}$ in diameter, a smooth surface with no signs of peeling, the color is from light gray to pinkish-brownish. Subjective symptoms are often absent, in 10-15\% of cases itching occurs [6]. Macular and maculapapular forms of mastocytosis must be differentiated from pigmented nevi, macular idiopathic pigmentation, drug toxicoderma $[2,5]$.

Telangiectasiamacularis eruptive perstansis a rare form of mastocytosis, occurring predominantly in adults [8]. It is clinically manifested by brownish or reddish maculas within which small telangiectasias are visible, $1-5 \mathrm{~mm}$ in size. On the body of the rash is always more than on the limbs.

Mastocytosis is characterized by Darier'ssignand urticarial dermographism [2,5]. This form is differentiated from Rotmund - Thomson congenital poikiloderma, Jacobi atrophic vascular poikiloderma, and Gouger - Blum purulent angiodermite $[3,6]$.

In the diagnosis of mastocytosis, the characteristic clinical picture and the positive Darier'ssignare of primary importance. This sign is that with vigorous rubbing of any lesion, erythema and swelling of the rash appear.

Differential diagnostics is carried out with café-au-lait macules, Spitz or congenital melanocytic nevi, pseudolymphomas, and juvenile xanthogranulomas[2].

\section{Clinical Case}

Patient N, born in 2002, came to the Department of Dermatovenereology of the Azerbaijan Medical University with complaints of a rash on the skin located on the back surface of both hands. According to the patient, the rash appeared in 2016. There are no subjective complaints. An objective examination revealed spotty elements with well-defined edges, round and oval in shape, with a diameter of 1.0-3.0 $\mathrm{cm}$. Lichenificationis observed on some spots, and small plate peeling on the other spots. Dark brown spots. The patient turned to various clinics, where he was diagnosed, such as "contact allergic dermatitis", "erythema multiforme exudative". Positive dynamics during treatment was not observed.

When the patient applied to the Department of Dermatovenereology of the Medical University, the following studies were carried out: complete blood count, biochemical blood test, as well as determination of rheumatoid factors. As a result of laboratory tests, no pathology was identified.

To clarify the diagnosis, the patient was sent for histopathological examination. A biopsy was taken from the pathological focus of the posterior surface of the right hand, 6-7 $\mathrm{mm}$ in size on 10.11.18. As a result of histopathological research, the following changes were identified: in the epidermis - hyperparakeratosis, acanthosis, papillomatosis, marked spongiosis with the formation of intraepidermal blisters, hyperpigmentation of the basal layer; in the dermis - acute edema, lymphohistiocytic infiltration of inflammatory origin with perivascular scattered basocytemastocytoma in the papillary dermis, expansion of the superficial capillaries. In addition, fragments of hair follicles and eccrine glands were found in the preparation.

The found histopathological changes are characteristic oftelangiectasiamacularis eruptive prestans, which is a form of mastocytosis.

The treatment uses antihistamines and local glucocorticoids. Potent topical corticosteroids, especially under occlusion for 5 - 6 weeks, may eliminate pruritus and cutaneous whealing as well as reduce the number of lesional skin mast cells, but this can also lead to skin atrophy [2].

Thus, the presented clinical case reflects the urgency of the problem of mastocytosis, since this disease is rare and causes difficulties in the diagnosis. 

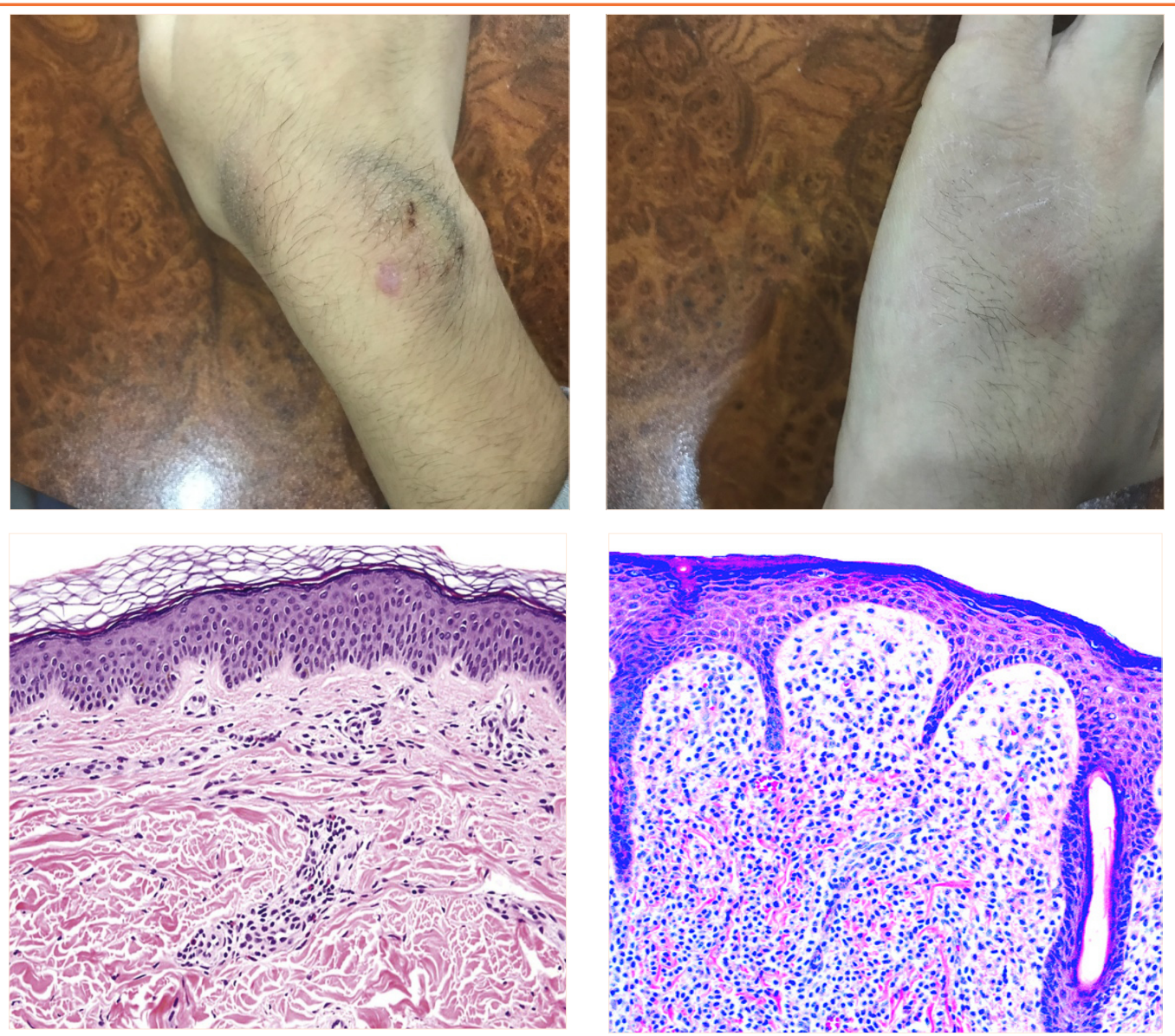

\section{REFERENCES}

[1] Лебедева Т.Ю., Федерякина О.Б., Дубенский B.В., Катунина О.Р. Мастоцитоз у детей // Тверской мед. ж. - 2014. - №1. - С. 48-61. [Lebedeva T.Y., Federyakina O.B., DubenskyVl.V.,Katunina O.R. Mastocytosis in children. Tverskoymeditsinskiyzhurnal.2014; 1 : 48-61.(In Russ.)]

[2] Jean L. Bologna, Julie V. Schaffer, Lorenzo Cerroni, forthedition .2018, Elsevier Limited. 2672e3 p.

[3] ПальцевМ.А., ПотекаевН.Н.,КазанцеваИ.А. идр. Клинико-морфологическаядиагностика заболеванийкожи. - М.:Медицина, 2005. 484 c. [Pal'tsevM.A., PotekaevN.N., KazantsevaI.A. Kliniko-morfologicheskayadiagnostikazaboleva niykozhi. (Clinical and morphological diagnosis of skin diseases.) Moscow: Meditsina. 2005: 484 p. (In Russ.)]

[4] Потекаев Н.С., Потекаев Н.Н. Мастоцитоз. В кн.: Клиническая дерматовенерология /

Под ред. Ю.К. Скрипкина, Ю.С. Бутова - М.: ГЭОТАР-Медиа, 2009. - т. 2. - С. 535-544. [Potekaev N.S., Potekaev N.N. Mastocytosis, in Klinicheskayadermatovenerologiya.(Clinical dermatovenerology.)Ed. by Yu.K.Skripkin, Yu.S. Butov. Moscow: GEOTAR-Media. 2009; Vol. 2: 535-544. (In Russ.)].

[5] К.Вульф, Р. Джонсон, Д.Сюрмонд. ДерматологияпоТомасуФицпатрику. Атлассправочник. Второе русское издание. Пер. с англ. - М., «Практика», 2007. -1248 с.

[6] Скрипкина Ю.К., Бутова Ю.С., Иванова О.Л. Дерматовенерология. Национальноеруководство. - М.: ГЭОТАРМедиа, 2013. - 896 с. [SkripkinaYu.K., ButovaYu.S.,IvanovaO.L. Dermatovenerologiya. Natsional'noerukovodstvo. (Dermatovenerology. National guidelines.) Moscow: GEOTAR-Media. 2013: 896 p. (In Russ.)] 
[7] Хегер П.Г. Детская дерматология / Пер. с нем. под ред. А.А. Кубановой, А.Н. Львова. - М.: Издательство Панфилова; БИНОРМ. Лабораториязнаний, 2013. - 648 c. [Р.H. Höger. Kinderdermatologie.Schattauer. 2011: 664 p. RussEd.: P.H. Höger. Detskayadermatologiya. Moscow: Izdatel'stvoPanfilova; BINORM. Laboratoriyaznaniy.2013: 648 p.]
[8] NooshinK.Brinster, Vincent Liu, A. HateezDiwan, Phillip H. McKee. Dermatopathology, 2011. Elsevier

Citation: Makhmudov.F.R, Obeidat M.A, Mizher S.A. Clinical Case of Mastocytosis. Archives of Dermatology and Skin Care. 2020; 3(2): 17-20.

Copyright: (C) 2020 Makhmudov.F.R, Obeidat M.A, Mizher S.A. This is an open access article distributed under the Creative Commons Attribution License, which permits unrestricted use, distribution, and reproduction in any medium, provided the original work is properly cited. 